\title{
Honey Mesquite Control and Forage Response in Crane County, Texas
}

\author{
P.W. JACOBY, C.H. MEADORS, M.A. FOSTER, AND F.S. HARTMANN
}

\begin{abstract}
Replicated field plots of honey mesquite (Prosopis glandulosa var. glandulosa) were aerially treated with herbicides in 1977 near Crane, Texas. Plots were evaluated for 3 years to determine efficacy of nine herbicide formulations. Of the herbicides studied 3,6-dichloropicolinic acid was the most effective. Sprayed plots produced twice as much forage as unsprayed areas with several species of grass showing significant increases in production. Forb response was not significantly different between treated and untreated plots. Most of the forage response occurred $1 \mathrm{~m}$ from the tree base rather than at 3 and $5 \mathrm{~m}$ from the tree.
\end{abstract}

Herbicides remain an economical and efficient method for controlling large areas of mesquite. However, the controversies surrounding the use of $2,4,5-\mathrm{T}$ [ $(2,4,5$ trichlorophenoxy) acetic acid] have threatened its continued use. Two new herbicides, triclopyr $\{[(3,5,6$-trichloro-2-pyridinyl)oxy]acetic acid $\}$ and 3,6-DPA (3,6dichloropicolinic acid), have recently been evaluated for mesquite control (Jacoby et al. 1980, 1981).

Aerial spraying of mesquite with $2,4,5-\mathrm{T}$ and 1:1 mixture of 2,4,5-T + picloram (4-amino-3,5,6-trichloropicolinic acid) or dicamba (3,6-dichloro-o-anisic acid) has provided temporary suppression of mesquite as well as increased forage production (Scifres 1980). Degree of forage response following mesquite control has been related to: (1) mesquite size and density (Williams 1976); (2) rainfall following treatment (Cable 1976, Martin 1975); (3) degree of control (Dahl et al. 1978); and (4) the condition and composition of the understory herbaceous community (McDaniel et al. 1978, Scifres and Polk 1974). Generally, most dramatic forage responses following brush suppression have occurred in arid to semiarid areas where competition between brush and grass is critical. Studies conducted in Arizona by Cable (1976), Martin and Tschirley (1961), and Parker and Martin (1952) have shown increased forage production from mesquite control over long periods of time following treatment.

Specific competitive factors between mesquite and associated grasses have been delineated. Tiedemann and Klemmedson (1973) found that soils were more fertile under mesquite trees than in the open interspaces. Certain plants including Arizona cottontop (Digitaria californica), bristlegrass (Setaria texana), and bush muhly (Muhlenbergia porterii) were found to adapt to shaded conditions beneath mesquite canopies, while plants such as black grama (Boutelowa eriopoda) were shade intolerant (Tiedemann et al. 1971). Brock et al. (1978) determined that cool-season forage species found mainly in the canopy zone decrease following mesquite control in northcentral Texas. Cable (1977) defined zones of

\footnotetext{
Authors are associate professor, research associate, and former research associate, Texas Agr. Exp. Sta., Vernon 76384, and assistant to manager, Surface Lands, University of Texas Lands, Midland 79701 .

Manuscript received June 18, 1981. Technical article TA-16917 from the Texas Agric. Exp.Sta. Study was a cooperative investigation of Texas Agr. Exp. Sta. and University of Texas Lands.

The authors express their appreciation to J.R. Bell, Garth Grizzle, J.B. Averitt, and Tomas Dominguez with the Soil Conservation Service, U.S. Dep. Agric. for their assistance in collecting the forage production data. We also wish to thank Billy Carr, Manager, Surface Leasing, University Lands for suggesting and supporting this study. Funds for this research were provided by the University of Texas Lands-Surface Leasing, Midland Texas. Herbicides were provided by Dow Chemical Co., U.S.A., and Velsicol Chemical Co. Application of herbicides was by $\mathrm{H} \& \mathrm{~W}$ Flying Service, Midland, Texas.
}

moisture use around mesquite plants with moisture depletion occurring rapidly near tree bases, decreasing with depth and distance from the tree. Thomas and Sosebee (1978) found that mesquite in western Texas relies on a system of shallow lateral roots when moisture is available in the upper soil profile and utilizes a deep tap root system during drought.

The objectives of this study were to determine relative efficacies of registered and experimental herbicides for mesquite control and to estimate plant responses of associated forage species in sprayed and nonsprayed plots.

\section{Study Area and Methods}

Studies were conducted on rangeland $6 \mathrm{~km}$ northwest of Crane in western Texas. Climate is semiarid with an average of $33 \mathrm{~cm}$ annual rainfall occurring mainly in late spring and summer. Soils in the study area are sands and sandy loams in the Penwell (Ustic Torripsamments), Jalmar and Pyote (Ustalfic Haplargids) series (Watson 1978). Soils are mainly sandy loams in the southern end of the area becoming more sandy to the north. Native vegetation on the arca is dominated by shrubs including honcy mesquitc, catclaw acacia (Acacia greggii), and fourwing saltbush (Atriplex canescens). Grasses dominate the understory and include Wright threeawn (Aristida wrightii), sand dropseed (Sporobolus cryptandrus), mesa dropseed (Sporobolus flexuosus), bristlegrass, Arizona cottontop, black grama, bush muhly, and hooded windmillgrass (Chloris cucullata). Major forbs are leatherweed croton) (Croton pottsii) and broom snakeweed (Xanthocephalum sarothrae).

The study area was subdivided into 30 plots ( $102 \times 402 \mathrm{~m}$ each) to accommodate a randomized complete block design comprised of nine treated plots and an untreated check plot in each of three blocks. The area was blocked to account for soil variation. Blocks were delineated by four parallel access paths bulldozed $402 \mathrm{~m}$ apart. The experimental design was modified by randomizing order of treatment application but using the same order of treatment installation in each block. Treatments were offset in each block to insure that similar treatments were not together in adjacent blocks. Herbicides were aerially applied in late May 1977. Each treatment consisted of six parallel spray swaths each measuring 12 by $402 \mathrm{~m}$. Untreated buffer zones $30 \mathrm{~m}$ wide were maintained between plots to minimize cross-treatment herbicide movement and to facilitate field evaluations. All herbicide treatments were applied at a $0.56 \mathrm{~kg} /$ ha (a.e.) rate in $9.4 \mathrm{~L} /$ ha volume of $1: 7$ (v:v) diesel oil and water emulsion. Herbicides were mixed for each treatment in an open vat with constant recirculating agitation. Measured amounts of herbicide and diesel oil were poured simultaneously from separate containers into a premeasured amount of recirculating water to form the emulsion. The aircraft was calibrated prior to treatment, loaded through the hopper, and following treatment, drained of residual spray solution which was measured to substantiate proper treatment volume. Aircraft systems were washed and purged between each treatment to prevent herbicide contamination among treatments. Herbicides included in the experiment were: $2,4,5-\mathrm{T}^{1}$ alone and in combination $(1: 1)$

\footnotetext{
12,4,5-T as the propylene glycol butyl ether ester
} 
Table 1. Mean plant defoliation (\%) and mortality (\%) of honey mesquite treated in May 1977 and evaluated 18 and 30 months following treatment near Crane, Texas. ${ }^{1}$

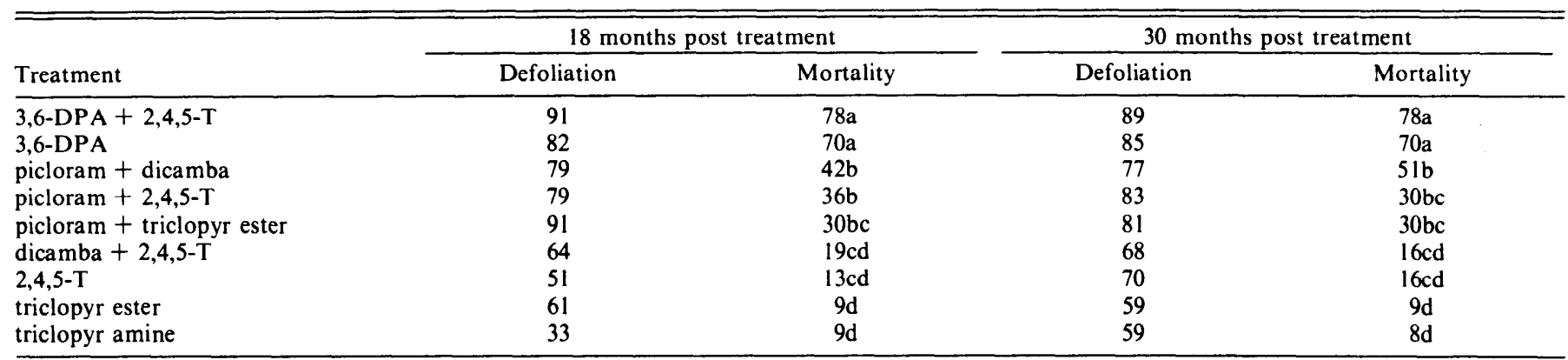

'Means within a column followed by the same letter are not significantly different at the $5 \%$ level.

with picloram ${ }^{2}$, dicamba ${ }^{3}$, and 3,6-DPA ${ }^{4}$ : ester and amine formulations of triclopyr ${ }^{5}$, and triclopyr ester with picloram (1:1); 3,6DPA; and an equal part combination of dicamba and picloram.

Treatments were evaluated 6 months post-treatment by visually estimating percentage defoliation in each plot. Subsequent evaluations were made 18 and 30 months post-treatment using belt transects in which 100 or more individual mesquite plants were evaluated visually in each plot to estimate plant defoliation and mortality.

In November 1979, 30 months post-treatment, obvious differences in forage production between treated and untreated plots warranted estimates of forage production to be measured by clipping standing grass and forb biomass. Forage production estimates were made between untreated plots and plots treated with 3,6DPA due to the close proximity of the two plots in each block and the effective control of mesquite by 3,6-DPA.

Within each block ten trees of equivalent size were selected in each of the treated and untreated plots. Trees in the check plots were unaffected by spray while those in the 3,6-DPA plots were dead. Quadrats $0.25 \mathrm{~m}^{2}$ in size were placed 1,3 , and $5 \mathrm{~m}$ from the tree base on the east side of each plant. Within each quadrat, individual plant species were clipped, bagged separately, and subsequently oven-dried to a constant weight. All data were subject to analyses of variance and mean separation.

\section{Results and Discussion}

Estimation of canopy reduction made in November 1977, 6 months post-treatment, revealed more than $90 \%$ defoliation in all herbicide treatment except 2,4,5-T, triclopyr amine and dicamba + 2,4,5-T which were slightly lower. Buffers between plots were largely unaffected, validating lack of herbicide drift across plots. Reduction in broom snakeweed cover was noted in treatments

\footnotetext{
2Picloram as the triisopropanolamine salt

${ }^{3}$ Dicama as the dimethylamine salt

43,6-DPA as the monoethanolamine salt

${ }^{5}$ Triclopyr as the butoxy ethyl ether ester and the triethylamine salt.
}

containing picloram or triclopyr ester. Grass responses were not visually evident the first year of treatment.

Evaluations of mesquite defoliation and mortality made in November 1978 and 1979,18 and 30 months post-treatment, respectively, revealed major differences in herbicide efficacies (Table 1). Herbicide 3,6-DPA was significantly more effective than the other herbicides, whether applied alone or in equal part combination with $2,4,5-\mathrm{T}$. Triclopyr, provided similar control to $2,4,5-\mathrm{T}$ and $2,4,5-T+$ dicamba $(1: 1)$, while herbicides containing picloram gave higher mortality of mesquite than triclopyr. No significant differences occurred among blocks.

Associated shrubs such as fourwing saltbush were slightly defoliated initially by herbicide combinations containing picloram but

Table 2. Mean standing crop of grasses and forbs (kg/ha) estimated 30 months post-treatment at 1,3 , and $5 \mathrm{~m}$ distances from sprayed and nonsprayed mesquite trees near Crane, Texas. ${ }^{1}$

\begin{tabular}{crrrrr}
\hline \hline \multirow{2}{*}{$\begin{array}{l}\text { Distance from } \\
\text { tree base }(\mathrm{m})\end{array}$} & \multicolumn{2}{c}{ Treated } & & \multicolumn{2}{c}{ Untreated } \\
\cline { 2 - 3 } \cline { 5 - 6 } \cline { 5 - 6 } & Grasses & Forbs & & Grasses & Forbs \\
\hline & & \multicolumn{2}{c}{$\mathrm{kg} / \mathrm{ha}$} \\
3 & $1165.4 \mathrm{a}$ & $373.6 \mathrm{c}$ & $457.4 \mathrm{c}$ & $333.8 \mathrm{c}$ \\
5 & $715.7 \mathrm{~b}$ & $130.0 \mathrm{~d}$ & & $454.5 \mathrm{c}$ & $196.6 \mathrm{~d}$ \\
& $834.8 \mathrm{~b}$ & $140.2 \mathrm{~d}$ & & $336.1 \mathrm{c}$ & $91.1 \mathrm{~d}$ \\
\hline
\end{tabular}

Values followed by the same letter are not significantly different at the $5 \%$ level.

these effects were not evident 30 months following treatment. Catclaw acacia plants were severely defoliated but a majority of the plants resprouted 30 months after treatment.

Forage production, as end of growing season standing crop, was significantly greater in herbicide treated plots sprayed with 3,6DPA than adjacent untreated plots (Table 2). Major differences between the treatments were contributed by the grass components because the major forb, leatherweed croton, was not affected by the herbicide treatment. Greatest grass response was measured at 1 $\mathrm{m}$ from mesquite trees in the treated plots. Differences in grass

Table 3. Mean standing crop (kg/ha) by species estimated 30 months post-treatment in sprayed and non-sprayed plots at 1,3 , and $5 \mathrm{~m}$ from base of trees near Crane, Texas. ${ }^{1}$

\begin{tabular}{|c|c|c|c|c|c|c|}
\hline & \multicolumn{3}{|c|}{ Treated } & \multicolumn{3}{|c|}{ Untreated } \\
\hline & $1 \mathrm{~m}$ & $3 m$ & $5 \mathrm{~m}$ & $3 \mathrm{~m}$ & $5 \mathrm{~m}$ & \\
\hline Aristida wrightii & $5 d$ & $372 a$ & $344 a b$ & $34 d$ & $253 \mathrm{bc}$ & $196 c$ \\
\hline Chloris cucullata & $502 a$ & $150 \mathrm{bc}$ & $216 \mathrm{~b}$ & $207 \mathrm{~b}$ & $74 c$ & $64 \mathrm{c}$ \\
\hline Panicum havardii & $99 a$ & $33 \mathrm{bc}$ & $74 a b$ & $29 \mathrm{bc}$ & $8 \mathrm{c}$ & $28 b c$ \\
\hline Setaria texana & $208 a$ & ob & $0 \mathrm{~b}$ & $55 b$ & $0 \mathrm{~b}$ & $\mathrm{Ob}$ \\
\hline Sporobolus cryptandrus & $232 a$ & $149 \mathrm{ab}$ & $140 \mathrm{abc}$ & $130 \mathrm{bc}$ & $118 \mathrm{bc}$ & $45 \mathrm{c}$ \\
\hline Other grasses & $70 a$ & $12 \mathrm{bc}$ & $60 \mathrm{ab}$ & $2 \mathrm{c}$ & $0 \mathrm{c}$ & $2 \mathrm{c}$ \\
\hline Croton pottsii & $361 a$ & $120 \mathrm{c}$ & $122 \mathrm{c}$ & $326 a b$ & $196 \mathrm{bc}$ & $91 \mathrm{c}$ \\
\hline Other forbs & $13 \mathrm{ab}$ & $10 \mathrm{ab}$ & $18 \mathrm{a}$ & $7 b c$ & $0 \mathrm{c}$ & $0 \mathrm{c}$ \\
\hline
\end{tabular}

${ }^{1}$ Mean values within a row not followed by the same letter are significantly different at the $5 \%$ level (Duncan's multiple range test). 
production among the 1,3 , and $5 \mathrm{~m}$ distances in the untreated plots were not significantly different while forb production was greatest near the trees. Significant differences in overall grass, forb or forage (grass + forbs) production were not found a mong blocks,although individual species displayed considerable variation among blocks and distances from trees (Table 3). Forbs, especially annuals, would have probably been higher if sampling had occurred in late spring.

\section{Reaction of the Various Species}

Wright threeawn was a fairly ubiquitous species but was more productive on the loamy soils of the study area. Treated plots produced significantly $(P<0.05)$ more production than untreated plots. Both treated and untreated plots had significantly $(P<0.01)$ more production away from the tree $(3$ and $5 \mathrm{~m})$ than near the tree $(1 \mathrm{~m})$. Wright threeawn showed a general affinity for open areas of loamy soils and responded positively to mesquite control.

Hooded windmillgrass was most responsive to mesquite control and contributed greatly to overall forage production in the treated plots. This species produced significantly $(P<0.01)$ more forage in treated areas than in untreated a reas. Hooded windmillgrass produced significantly $(P<0.01)$ more forage near the trees than in open areas and favored the lighter textured soils.

Harvard panicum (Panicum harvardii) was found in significantly $(P<0.01)$ greater amounts on the treated area than in the untreated plots. While overall production did not vary greatly among the distances from trees, significant $(P<0.01)$ variation occurred among the blocks, with practically all production being measured on loamy soils.

Bristlegrass occurred in the immediate proximity of mesquite trees where production quadrupled following mesquite control. This interspecific relationship suggests the presence of a favorable habitat for bristlegrass, such as physical protection from grazing, and improved nutrient, moisture and shading factors (Brock 1978).

Sand dropseed and mesa dropseed production was greatest in the treated area but did not vary significantly among distances from trees. Production differences among blocks were not significant.

Grass production from species other than those previously mentioned was found mainly on the treated sandy range site and included species such as mat sandbur (Cenchrus pauciflorus), muhly (Muhlenbergia spp.), bristle panicum (Panicum ramisetum), and fluffgrass (Erioneuron pulchellum). No significant differences were found among distances from trees.

Leatherweed croton was the major forb present at the time of sampling. This unpalatable perennial plant was unaffected by herbicide 3,6-DPA and was distributed over the entire study area. Significantly $(P<0.01)$ more production of this species occurred near mesquite trees than at the 3 and $5 \mathrm{~m}$ distances.

This study quantifies the production differences resulting from effective mesquite control by herbicidal spraying and the vegetative responses by various plant species of the eocsystem. These data support earlier work by McDaniels et al. (1978) and Brock et al. (1978) and tend to substantiate certain benefits of aerial spraying for forage production. These data illustrate that the canopy area of controlled mesquite plants is a major source of forage plants. The physical presence of the dead plants offers a degree of protection from grazing, allowing valuable plants released by the spraying treatment to produce seed and reestablish on the adjacent rangeland. The importance of the canopy area should be recognized when considering mechanical removal of dead trees following treatment.

\section{Literature Cited}

Brock, J.H. 1978. Influence of honey mesquite and its control on zonal vegetation patterns. Unpublished dissertation. Texas A\&M Univ., College Station. 201 p.

Brock, J.H., R.H. Haas, and J.C. Shaver. 1978. Zonation of herbaceous vegetation associated with honey mesquite in northcentral Texas. Proc. First Internat. Rangeland Congr. Denver, Colo. p. 187-189.

Cable, D.R., and F.H. Tschirley. 1961. Responses of native and introduced grasses following aerial spraying of velvet mesquite in southern Arizona. J. Range Manage. 14:155-159.

Cable, D.R. 1976. Twenty years of changes in grass production following mesquite control and reseeding. J. Range Manage. 29:286-289.

Cable, D.R. 1977. Seasonal use of soil water by native velvet mesquite J. Range Manage. 30:4-11.

Dahl, B.E., R.E. Sosebee, J.P. Goen, and C.S. Brumley. 1978. Will mesquite control with 2,4,5-T enhance grass prodution? J. Range Manage. 31:129-131.

Jacoby, P.W., C.H. Meadors, and M.A. Foster. 1980. Triclopyr herbicide for control of honey mesquite. Texas Agr. Exp. Sta. Consold. Prog. Rep. 3665 , p. 26-27.

Jacoby, P.W., C.H. Meadors, and M.A. Foster. 1981. Control of honey mesquite (Prosopis juliflora var. glandulosa) with 3,6-dichloropicolinic acid. Weed Sci. 29:376-378.

Martin, S.C. 1975. Ecology and management of southwestern semidesert grass-shrub ranges. U.S. Dep. Agr. Forest Serv. Res. Pap. RM-156. Rocky Mtn. Forest and Range Exp. Sta., Fort Collins, Colo. 35 p.

McDaniel, K.C., R.H. Haas, and J.H. Brock. 1978. Range condition trends following control of honey mesquite (Prosopis glandulosa var. glandulosa) on deep hardlands in northcentral Texas. Proc. First Internat. Rangeland Cong., Denver, Colo. p. 530-533.

Parker, K.W., and S.C. Martin. 1952. The mesquite problem on southern Arizona ranges. U.S. Dep. Agr. Forest Serv. Circ. No. 908., Washington, D.C. $70 \mathrm{p}$.

Scifres, C.J., and D.B. Polk, Jr. 1974. Vegetation response following spraying a light infestation of honey mesquite. J. Range Manage. 27:462465.

Scifres, C.J. 1980. Brush management-principles and practices for Texas and the Southwest. Texas A\&M Univ. Press, College Station. 360 p.

Thomas, G.W., and R.E. Sosebee. 1978. Water relations of honey mesquite a faculative phreatophyte. Proc. First Internat. Rangeland Cong., Denver, Colo. p. 414-418.

Tiedemann, A.R., and J.O. Klemmedson. 1973. Effect of mesquite on physical and chemical properties of the soil. J. Range Manage. 26:27-29.

Watson, L. 1978. Soil survey of Ect or and Crane Counties, Texas U.S. Dep. Agr. Soil Conserv. Serv. 89 p.

Williams, P.T. 1976. Grass production changes with mesquite (Prosopis juliflora) reinvasion in southern Arizona. M.S. Thesis, Univ. Arizona, Tucson. $36 \mathrm{p}$. 